\title{
RESPONSE TO REASONABLE EXPECTATIONS IN SOCIOCULTURAL CONTEXT
}

\author{
David G. Epstein*
}

Under the leadership of Dean Blake Morant, ${ }^{1}$ the Wake Forest Law Review (the "Law Review") presented a symposium: Contracts in Context: Identity, Power and Contractual Justice. Robert Samuel, the Executive Forum Editor of the Law Review, has asked me to write a short scholarly ${ }^{2}$ response ${ }^{3}$ to one of the papers presented at the symposium and later published in the Law Review, Reasonable Expectations in Sociocultural Context (the "Article") ${ }^{4}$ by Professor Nancy S. Kim. ${ }^{5}$

The Article starts ${ }^{6}$ (and ends) ${ }^{7}$ with the premise that contract law should enforce the reasonable expectations of the parties. This is a hard premise to challenge. ${ }^{8}$ And an even harder premise to

* George E. Allen Chair, University of Richmond Law School

1. Fourteen years ago, Dean Morant had written on contract law in context. Blake D. Morant, The Relevance of Race and Disparity in Discussions of Contract Law, 31 NEW ENG. L. REV. 889, 890-99 (1997).

2. In responding to Robert's kind invitation, I told him that, unlike Dean Morant, Professor Kim, and the other Symposium participants, I am not a contracts scholar; I just teach contract law to law students and law school graduates studying for the bar exam. Nonetheless, I have written this short response, which I hope is "scholarly" enough, because like everyone involved in higher education (only more so), I am indebted to the late Tom Hearn, President of Wake Forest University for twenty-two meaningful years.

3. I kind of feel like the $a^{* *}$ hole that ruins faculty forums by running on about his view of the presenter's paper. Cf. Sally Jane, Workshop Etiquette, The CReative Writing M.F.A. BlOG (Dec. 13, 2010, 7:33 PM), http://creative -writing-mfa-handbook.blogspot.com/2010/12/workshop-etiquette.html (explaining the old joke that if you look around and do not see an a**hole in a room, you are the $a^{* *}$ hole). I hope Professor Kim prepares a devastating rejoinder showing how I misunderstood her article.

4. Nancy S. Kim, Reasonable Expectations in Sociocultural Context, 45 WAKE FOREST L. REV. 641 (2010).

5. I do not think I know Professor Kim. However, I do know Professor Kim's work. One of Professor Kim's earlier articles is cited in a contracts casebook I coauthor. DAVID G. EPSTEIN ET AL., MAKING AND DoING DEALS: CONTRACTS IN CONTEXT 626, 628 (3d ed. 2011) (My casebook coauthors want Professor Kim to know that they both love Reasonable Expectations in Sociocultural Context.)

6. Kim, supra note 4 , at $641-42$.

7. Id. at 668 .

8. It would mean challenging not only Professor Kim but also Arthur Linton Cobrin. See id. at 642 n.3. 
apply. ${ }^{9}$

The Article recognizes the two problems with applying this premise: (1) how does a court decide what expectations are "reasonable," and (2) what does a court do when the contracting parties have different reasonable expectations. ${ }^{11}$ The Article then uses two cases to illustrate how "sociocultural dissonance between a judge and contracting party"12 exacerbates these problems.

There must be a lot of "sociocultural dissonance between a judge and a contracting party" who appears before her in terms of education, income, and social status. ${ }^{13}$ I am just not sure that there are a lot of cases in which that matters-at least not a lot of reported cases. For instance, Leonard $v$. Pepsico, Inc. ${ }^{14}$ - the example of such sociocultural dissonance most familiar to law students ${ }^{15}$-arose from a Pepsi promotional campaign in which "Pepsi Points" could be redeemed for various prizes. Justin Leonard, a twenty-one-year-old member of the "Pepsi Generation" to whom Pepsi intended the commercial to appeal, sees a commercial offering a Marine Harrier fighter jet for 7,000,000 Pepsi Points and submits an order form to Pepsi.

After Pepsi responded, "The Harrier jet in the Pepsi commercial is fanciful and is simply included to create a humorous and entertaining ad," Leonard sued for specific performance. ${ }^{16}$ When Pepsi moved for summary judgment, Leonard's attorney argued that

9. I know that this is a sentence fragment but my eleventh grade English teacher, Miss Alice Lindemann, told me that once I had a book published I could use sentence fragments.

10. Kim, supra note 4, at 646. See also John Phillips, Protecting Those in a Disadvantageous Negotiating Position: Unconscionable Bargains as a Unifying Doctrine, 45 WAKE FOREST L. REV. 837, 839 (2010) ("The problem is that different judges view the reasonable expectations of the parties in quite different ways, leading to diametrically opposing views as to the meaning of the same document.").

11. Kim, supra note 4 , at $646-47$.

12. Id. at 652. See also Larry A. DiMatteo \& Blake D. Morant, Contract in Context and Contract as Context, 45 WAKE Forest L. REv. 549, 573 (2010) ("Her article asserts that courts should take into consideration the social and cultural backgrounds and identities of the parties in analyzing contract disputes.”).

13. Kim, supra note 4, at 652. But cf. William H. Honan, Roman L. Hruska Dies at 94; Leading Senate Conservative, N.Y. TImEs, Apr. 27, 1999, at B8, available at http://www.nytimes.com/1999/04/27/us/roman-l-hruska-dies-at-94 -leading-senate-conservative.html ("Even if [Supreme Court nominee Judge Harold Carswell] were mediocre...there are a lot of mediocre judges and people and lawyers."). The Paper makes the somewhat different point that there are a lot of sociocultural differences, if not sociocultural dissonance, among judges. See Kim, supra note 4, at 650-51.

14. Leonard v. Pepsico, Inc., 88 F. Supp. 2d 116, 118-19 (S.D.N.Y. 1999), aff'd, 210 F.3d 88 (2d Cir. 2000).

15. See, e.g., David G. Epstein et al., Making and Doing Deals: Contracts in Context 51 (2d ed. 2006); Christina L. Kunz \& Carol L. Chomsky, CONTRACTS: A CONTEMPORARY APPROACH 47, 78 (3d ed. 2011).

16. Leonard, 88 F. Supp. $2 d$ at 120. 
a federal judge comes from a "narrow segment of the enormously broad American socio-economic spectrum," and, thus, that the question whether the commercial constituted a serious offer must be decided by a jury composed of, inter alia, members of the "Pepsi Generation," who are, as plaintiff puts it, "young, open to adventure, willing to do the unconventional."17

Plaintiff's argument was essentially that a federal judge would view his claim differently than would fellow members of the "Pepsi Generation." ${ }^{18}$ Judge Kimba Wood ${ }^{19}$ correctly and deftly laid out why no reasonable person of any sociocultural category would regard the commercial as an offer to deliver a military jet costing more than $\$ 20,000,000$ to any person who provides "Pepsi Points" worth $\$ 700,000$. $^{20}$

\section{KIM V.SON}

Kim $v$. Son, ${ }^{21}$ the Article's first example of sociocultural dissonance, involved a personal promise by an owner of business entities to a friend that he would use his own funds to repay loans a friend had made to the promisor's business entities. Not surprisingly, the promisemaker later became a defendant promisebreaker. Not surprisingly, both the trial and the intermediate appellate court ruled that the "promise to repay the money was entirely gratuitous and unenforceable."22

It is easy to argue that the situation in Kim v. Son is one of many in which the requirement that a promise be supported by consideration produces a result that is inconsistent with the reasonable expectations of the parties. $^{23}$ The Article, however, makes the harder argument that it was the existence of the

17. Id. at 128 (citations omitted).

18. Id.

19. Litigators often say that knowing your judge is more important that knowing the law. Even discounting the value of this aphorism, before John Leonard's attorney made the tactical decision to argue that a jury, unlike Judge Wood, would be "young, open to adventure, willing to do the unconventional," he should have known more facts about Judge Wood-facts such as her being voted \#1 "Superhottie" of the female federal judiciary and her briefly training to be a Playboy bunny before attending Harvard Law School. See Dave Saltonstall, Quite An 'Other Woman' Brilliant Judge'll Survive Steamy Divorce Scandal, N.Y. DAILY NEws (Aug. 6, 1995), http://articles.nydailynews.com/1995-08 -06/news/17986978_1_harvard-law-school-leboeuf-bunny; Bodacious Babes of the Bench: The Female Superhotties of the Federal Judiciary!, UNDERNEATH THEIR ROBES (July 20, 2004), http://underneaththeirrobes.blogs.com/main/2004 /07/female_superhot.html.

20. Leonard, 88 F. Supp. $2 \mathrm{~d}$ at 129.

21. No. G039818, 2009 WL 597232 (Cal. Ct. App. Mar. 9, 2009).

22. Id. at *1.

23. Cf. P.S. AtiYah, An Introduction to the LaW of Contract 118 (5th ed. 1995) ("The 'doctrine' of consideration is generally seen by lawyers as a set of rules which limits the freedom of individuals to make binding legal promises."). 
sociocultural dissonance between the parties and the judge, and not the existence of the doctrine of consideration, that is to blame for a result inconsistent with the reasonable expectations of the parties.

There are three additional facts in Kim $v$. Son that seem important to the Article's sociocultural-dissonance argument: (1) both the promisor and the promisee (but not the trial court judge) were Koreans; (2) "saving face" is more important to Koreans than profit; ${ }^{24}$ and (3) "saving face" is the reason that the promisor made the promise. ${ }^{25}$ From these facts, the Article concludes that if the Court had looked to "the social and cultural value of saving face," ${ }^{, 26}$ it would have concluded that the promisor's relief from shame was a "legal benefit." "7

I do not know what the adjective "legal" adds to the word "benefit" that is not conclusory. ${ }^{28}$ I do know the argument that moral obligation should count as consideration has been made at least since the time of Lord Mansfield. ${ }^{29}$ And generally, this argument has been rejected. ${ }^{30}$ The reasons for the rejection do not include sociocultural dissonance.

Even if the judge in Kim $v$. Son had the benefit of the various references to Korean culture in the Article, he still would have concluded that, under the American law of consideration, the promise was not enforceable. Moreover, if the judge in Kim v. Son had determined that "relief from shame" was a "legal benefit" for a Korean promisor whose shame was "so great," the judge should have also found that relief from shame was a "legal benefit" for a Westerner with a less acute sense of shame. A "mere peppercorn's" worth of shame would have been enough. ${ }^{31}$ Again, the result in Kim

24. Kim, supra note 4, at 657-58.

25. Id. Kim's Article also emphasizes the fact that the note is written in blood and that "both men had consumed a large amount of alcohol." Id. at 655. The Paper then argues that "[t]he drawing of blood then may be understood as a way to show sincerity rather than as evidence of extreme intoxication" in Korean culture. Id. at 657.

26. Id. at 658 .

27. Id.

28. But cf. Manwill v. Oyler, 361 P.2d 177, 178 (Utah 1961) ("[I]f a mere moral, as distinguished from a legal, obligation were recognized as valid consideration for a contract, that would practically erode to the vanishing point the necessity for finding a consideration.").

29. "Where a man is under a moral obligation, which no Court of Law or Equity can inforce, and promises, the honesty and the rectitude of the thing is a consideration." Hawkes \& Uxor v. Saunders, (1782) 98 Eng. Rep. 1091 (K.B.) 1091.

30. See generally John Edward Murray, JR., Murray ON CONTRACTs $§ 67$ (4th ed. 2001).

31. See Perrymon v. Bullis, No. B207481, 2010 WL 189047, at *7 (Cal. Ct. App. Jan. 26, 2010) ("All the law requires is a mere peppercorn of consideration."). It is not surprising, but regrettable, that both the trial court and the intermediate appellate court in Kim v. Son used unnecessary (and misleading) adjectives such as "adequate" and "sufficient" before the noun 
$v$. Son is inconsistent with the reasonable expectations of the parties because of the elements of the doctrine of consideration-not because sociocultural dissonance caused the elements of the doctrine of consideration to be improperly applied.

\section{IN RE MARRIAGE OF WITTEN}

The Article also uses the case In re Marriage of Witten ${ }^{32}$ to illustrate sociocultural dissonance between the judge and a contracting party affecting reasonable expectations of a contracting party. Witten involved an "Embryo Storage Agreement" ("Agreement") entered into by Tamera Witten ("W") and Tripp Witten ("H"), who were married and about to engage in the process of in vitro fertilization. The Agreement provided that W and H's stored embryos could "be used for transfer, release or disposition only with the signed approval of both Client Depositors." ${ }^{33}$

Then, the Wittens divorced. In the divorce proceedings, W asked for "custody" of the embryos. H did not consent. The trial court ruled that the dispute over the embryos should be governed by the Agreement, which required both parties' consent to any disposition of the embryos. Accordingly, W did not gain custody of the embryos. ${ }^{34}$ The Iowa Supreme Court reached the same result, taking a very different approach: "judicial enforcement of an agreement between a couple regarding their future family and reproductive choices would be against the public policy ${ }^{35}$ of this state. $^{36}$ In other words-which happily are the words of the Iowa Supreme Court- "we reject the contractual approach." 37 The court then decided that, in the absence of a controlling agreement, the "better principle to apply, we think, is the requirement of contemporaneous mutual consent." ${ }^{38}$ Again, this was not a contractual approach $^{39}$ - the court found that the Agreement was not enforceable under these facts.

And again, as in the Article's first-principal case, we see another court's applying a contract law doctrine-unenforceability by reason

“consideration.” See David G. Epstein \& Yvette Joy Liebesman, Bearded Ladies Walking on the Brooklyn Bridge, 59 ARK. L. REV. 267, 304 n.192 (2006).

32. 672 N.W.2d 768 (Iowa 2003).

33. Id. at 772 .

34. Id. at $782-83$.

35. The court stated that it "must look to the Constitution, statutes, and judicial decisions of the state to determine its public policy." Id. at 780 (quoting Liggett v. Shriver, 164 N.W. 611, 612-13 (Iowa 1917)).

36. Id. at 782 .

37. Id.

38. Id. at 783 .

39. The court summarized prior judicial treatment of frozen embryo disputes as following either: (1) a contractual approach, (2) a balancing test, or (3) a contemporaneous mutual consent model. The court adopted the last approach. Id. at 774 . 
of public policy-that operates independently of the reasonable expectations of the parties. Decisions like Witten are based on the premise that "party autonomy is outweighed by some other interest." ${ }^{" 40}$ The cultural dissonance, if any, in Witten is between W and the Iowa legislature.

The Article suggests cultural dissonance in Witten between the presiding judge, Judge Marsha Temus, and W. More specifically, the Article posits that a woman such as Judge Temus was not "impervious to the male bias prevalent in society" give appropriate consideration to factors such as that "in vitro fertilization is a painful process for the woman [involved]"42 and that "the expense and improbability of $[(\mathrm{W})]$ being able to repeat the in vitro process." ${ }^{, 3}$

Other articles have used these and other factors to make the argument that public policy should favor the right of the woman, who has endured in vitro, to create over the right of the man, who merely supplied the sperm, not to procreate. ${ }^{44}$ The Article suggests a different argument for why $\mathrm{W}$ should get the embryos: promissory estoppel. Professor Kim wrote:

Trip made either an express or implied promise to Tamera that he would participate in the in vitro process with the goal of becoming a parent. Tamera acted in reliance upon this promise when she underwent the physically demanding procedure.... To conclude that Trip's promise should be enforceable to the extent of the reliance would permit Tamera to use the embryos. ${ }^{45}$

This assertion is a very creative promissory estoppel argument. The Article makes an even more creative cultural-dissonance argument. Recall that the court directly refused to enforce an express agreement about later use of embryos because of a public policy to respect "the right of individuals to make family and reproductive decisions based on their current views and values." And, that public policy came from statutes and case law. ${ }^{47}$

40. 2 E. Allan FARnsworth, FARnsworth ON CONTRACTS $§ 5.1$, at 2 (2d ed. 1998) (discussing public policy as a ground for unenforceability).

41. Kim, supra note 4 , at 663 .

42. Id. at 661 .

43. Id. at 662 .

44. See, e.g., Milandria King, Cold Shoulder Treatment: The Disposition of Frozen Embryos Post-Divorce, 25 T. MARSHALl L. REv. 99, 137 (1999); Ellen Waldman, Cultural Priorities Revealed: The Development and Regulation of Assisted Reproduction in the United States and Israel, 16 HEALTH MATRIX 65, 105 (2006) ("Once again, one spouse's desire to be a biological parent took a back seat to the other spouse's interest in avoiding unwanted biological ties.").

45. Kim, supra note 4 , at 667 .

46. In re Marriage of Witten, 672 N.W.2d 768, 782 (Iowa 2003).

47. Id. 
Assume, as the Article argues, that there was cultural dissonance between the judge and W. And assume, as the Article suggests, that had there not been any cultural dissonance between the judge and $\mathrm{W}$, the court would have recognized "an implied contract between Tamera and Trip whereby each promised the other to do their part to have biological children." ${ }^{48}$ The same public policies based on statutes and court decisions that respect "the right of individuals to make family and reproductive decisions based on their current views and values" ${ }^{\prime 49}$ should be as applicable to implied agreements as they are to express agreements.

As with cases involving agreements that are unenforceable because of the absence of consideration, cases involving agreements that are unenforceable because of public policy can be used to argue that contract law does not always enforce and protect the reasonable expectations of the parties. The argument that such cases-or at least the two cases in the Article-show that sociocultural dissonance between the parties and the judge causes decisions that do not reflect the reasonable expectations of the parties is, in the jargon law professors use, problematic. ${ }^{50}$

48. Kim, supra note 4 , at 666 .

49. Witten, 672 N.W.2d at 782.

50. I have always wanted to use the word "problematic" in a law review article. So do a lot of other people. A Westlaw search of "problematic" in the Journal and Law Reviews database showed 5438 hits for 2010. 